\title{
Influenza NG-34 T cell conserved epitope adjuvanted with CAF01 as a possible influenza vaccine candidate
}

\author{
Marta Sisteré-Oró ${ }^{1}$, Gabriel K. Pedersen², Lorena Córdoba', Sergi López-Serrano ${ }^{\text {, }}$ Dennis Christensen² \\ and Ayub Darji ${ }^{*}$ D
}

\begin{abstract}
Conserved epitopes are targets commonly researched to be part of universal vaccine candidates against influenza viruses (IV). These conserved epitopes need to be cross-protecting against distinct IV subtypes and to have a strong immunogenic potential. Nevertheless, subunit vaccines generally require a strong adjuvant to enhance their immunological effects. Herewith, we compare four different adjuvants differing in their immunological signatures that may enhance efficacy of a conserved hemagglutinin (HA)-epitope from IV, the NG-34, to define the most efficient combination of antigen/adjuvant to combat IV infections. Soluble NG-34 was mixed with adjuvants like aluminium hydroxide (AH) and AddaVax, known to induce Th2 and humoral responses; CAF01 which displays a biased Th1/Th17 profile and Diluvac Forte which augments the humoral response. Combinations were tested in different groups of mice which were subjected to immunological analyses. CAF01 + NG-34 induced a complete immune response with the highest IgG1, IgG2c titers and percentages of activated CD4 T cell promoting IFN- $\gamma$, IL-2 and TNF-a producing cells. Furthermore, in NG-34 stimulated mice splenocytes, cytokine levels of IFN- $\gamma, \mathrm{IL}-1 \beta, \mathrm{LL}-6, \mathrm{IL}-10, \mathrm{LL}-17$ and TNF-a were also the highest in the CAF01 + NG-34 mouse group. This complete induced immune response covering the humoral and the cellular arms of the adaptive immunity promoted by CAF01 + NG-34 group suggests that CAF01 could be a good candidate as an adjuvant to combine with NG-34 for an efficacious vaccine against IV. However, more studies performed in IV hosts as well as studies with a challenge model are further required.
\end{abstract}

\section{Introduction}

Purified antigens, mostly identified using in silico tools, are the constituants of subunit vaccines. These types of vaccines own numerous advantages when compared with the conventional inactivated-type vaccines, for instance: higher purity, greater safety (no need for special handling of infectious viruses) and a quicker massive production. Nevertheless, soluble antigens are often poorly immunogenic and require an adjuvant when the antigen is

\footnotetext{
*Correspondence: ayub.darji@irta.cat

${ }^{1}$ IRTA, Centre de Recerca en Sanitat Animal (CReSA, IRTA-UAB), Campus de la Universitat Autònoma de Barcelona, 08193 Bellaterra, Barcelona, Spain

Full list of author information is available at the end of the article
}

delivered [1]. This aspect makes the pursuit of a proper adjuvant important when developing subunit vaccines. The present study takes into account this aspect and combines an influenza virus hemagglutinin antigen (a conserved HA1-epitope NG-34) with four distinct adjuvants known to trigger different immune responses in order to determine the optimal antigen/adjuvant combination that may function effectively against IV.

Adjuvants are defined as substances whose main function is to enhance the ability of the vaccine to induce an appropriate immune response in the absence of adverse effects. Their mechanisms of adjuvanticity can be categorized accordingly to the criteria of O'Hagan and Valiante [2], which classifies them depending on their delivery

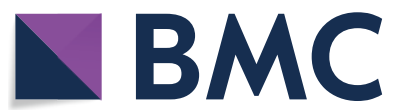

(c) The Author(s) 2020. This article is licensed under a Creative Commons Attribution 4.0 International License, which permits use, sharing, adaptation, distribution and reproduction in any medium or format, as long as you give appropriate credit to the original author(s) and the source, provide a link to the Creative Commons licence, and indicate if changes were made. The images or other third party material in this article are included in the article's Creative Commons licence, unless indicated otherwise in a credit line to the material. If material is not included in the article's Creative Commons licence and your intended use is not permitted by statutory regulation or exceeds the permitted use, you will need to obtain permission directly from the copyright holder. To view a copy of this licence, visit http://creativeco mmons.org/licenses/by/4.0/. The Creative Commons Public Domain Dedication waiver (http://creativecommons.org/publicdomain/ zero/1.0/) applies to the data made available in this article, unless otherwise stated in a credit line to the data. 
system and their immunopotentiation. However, few adjuvants are currently licensed [3-5] and a long delay exists in licensing new types. This is creating inconvenience for novel emerging vaccines, mainly since they cannot utilize novel adjuvants focused on exploring novel strategies, such as generating also robust cell-mediated immune (CMI) responses [6-8].

The seasonal updated Trivalent/Quadrivalent Inactivated Vaccine (TIV/QIV) commercially available against influenza viruses (IV), covers up to $90 \%$ of human vaccines worldwide [9]. Lamentably, immune responses induced are strain-specific and do not cope with possible mutations or probable new emerging strains caused by antigenic shift. For decades, the idea of developing a universal vaccine which provides a broad-spectrum protection against a variety of IV has been pursued. In order to achieve this challenge, inducing antibodies by immunizing with conserved regions of the viral proteins has been investigated. Nonetheless, these epitope-based vaccines usually confer short-lived protection and are compromised compared to current licensed vaccines [10]. In the present experimental study, we evaluated a suitable adjuvant candidate (novel and registered) immunologically to be mixed with a well-studied HA-epitope by our group [11], the NG-34. The study pursued a prototype for a universal vaccine, thus the murine model was used in preliminary research.

NG-34 peptide, predicted by Informational Spectrum Methodology (ISM) [12, 13], is located within the site $\mathrm{E}$ in the N terminus of HA1 [14], in a domain close to the receptor binding site (RBS) of the HA, characterized for being relatively conserved. Its role in inducing specific antibodies as well as CD4 $\mathrm{T}$ cells in the pig model has been documented. Recently, it has been shown that NG-34 was effective as a pig influenza vaccine in combating against a heterologous challenge by reducing shedding and inducing neutralizing antibodies against a SwH3N2 virus [11]. In poultry, another study supported its cross-protective effect against an H7 HPAIV strain [15].

The four adjuvants tested (Alhydrogel 2.0\%, AddaVax $^{\mathrm{TM}}$, cationic adjuvant formulation 01 (CAF01) and Diluvac Forte ${ }^{\circledR}$ ) were selected in view of their dissimilar immunological profiles and mechanisms of adjuvanticity (O'Hagan and Valiante [2]) summarized in Table 1. Among them, Alhydrogel 2.0\% and $\operatorname{AddaVax~}^{\mathrm{TM}}$ (similar to MF5 $9^{\circledR}$ ) are formulated in human registered vaccines while CAF01 is in clinical development stages [16]. Diluvac Forte ${ }^{\circledR}$, however, is applied only in veterinary studies and has been widely utilized in swine protein vaccines $[17,18]$. However, knowing that pigs are also natural influenza hosts and regarding its safety and its easy mass-vaccination delivery, we decided to include Diluvac Forte ${ }^{\circledR}$ as a suitable porcine influenza adjuvant candidate.

Significant differences in the induction of humoral as well as cellular immune responses were only observed when combinations of $\mathrm{AH}+\mathrm{NG}-34$ and CAF01 + NG-34 were used. However, a combination of CAF01+NG-34 was also effective in upregulating a wide array of cytokines as well as IgG2c antibodies, representing the most complete immune response. Nonetheless, further studies in influenza hosts are vital to evaluate the efficacy and effectiveness of the vaccine combination in natural IV infections.

Table 1 Characteristics of each of the four adjuvants employed

\begin{tabular}{|c|c|c|c|c|c|}
\hline Adjuvant name & $\begin{array}{l}\text { Adjuvant type/ } \\
\text { chemical constituents }\end{array}$ & Immunological profile & $\begin{array}{l}\text { Mechanism of action } \\
\text { (delivery system/ } \\
\text { immunopotentiation) }\end{array}$ & Stage of development & References \\
\hline $\begin{array}{l}\text { Alhydrogel }{ }^{\circledR} \text { referred } \\
\text { as } A H\end{array}$ & $\begin{array}{l}\text { Aluminum salts (Mineral } \\
\text { salts)/Aluminum } \\
\text { hydroxide }\end{array}$ & $\mathrm{T}_{\mathrm{H}} 2$, humoral & $\begin{array}{l}\text { Depot effect, delayed } \\
\text { clearance/Activate } \\
\text { Nalp3 inflammasome }\end{array}$ & $\begin{array}{l}\text { Both human and veteri- } \\
\text { nary licensed vaccines }\end{array}$ & {$[47-51]$} \\
\hline $\begin{array}{l}\text { AddaVax }^{\mathrm{TM}} \text { (Invivogen); } \\
\text { similar to MF59 }{ }^{\circledR}\end{array}$ & $\begin{array}{l}\text { Oil-in-water emulsion/ } \\
\text { Squalene and poly- } \\
\text { sorbate mixture }\end{array}$ & $\mathrm{T}_{\mathrm{H}} 2$, humoral & $\begin{array}{l}\text { Enhance antigen pres- } \\
\text { entation/Induce APC } \\
\text { maturation }\end{array}$ & $\begin{array}{l}\text { Licensed European } \\
\text { seasonal influenza } \\
\text { vaccines }\end{array}$ & {$[52-57]$} \\
\hline CAF01 & $\begin{array}{l}\text { Particulate: Cationic lipo- } \\
\text { some/Dimethyldiocta- } \\
\text { decylamonium (DDA) } \\
\text { and a,a'-trehalose-6,6'- } \\
\text { dibehenate (TDB) }\end{array}$ & $T_{H} 1, T_{H} 17$, humoral & $\begin{array}{l}\text { Protect antigen from } \\
\text { destruction/Induce } \\
\text { APC maturation }\end{array}$ & Phase 1 & {$[8,19,34,58,59]$} \\
\hline Diluvac Forte ${ }^{\text {TM }}$ & $\begin{array}{l}\text { Oil-in-water emulsion/a- } \\
\text { tocopherol }\end{array}$ & Humoral & $\begin{array}{l}\text { Enhance antigen pres- } \\
\text { entation/Induce APC } \\
\text { maturation }\end{array}$ & $\begin{array}{l}\text { Approved in Animal } \\
\text { Health }\end{array}$ & {$[17,18,60,61]$} \\
\hline
\end{tabular}

$\mathrm{T}_{\mathrm{H}}=\mathrm{T}$ helper; Nalp3 = NACHT, LRR and PYD domains-containing protein 3; APC = antigen presenting cells. 


\section{Materials and methods}

\section{Mice handling and experimental design}

Mouse experiments took place at Statens Serum Institut (SSI) animal facilities. For this adjuvant testing research study, a total of twenty-seven 7-8 week old female mice of the inbred strain C57BL/6 (Envigo, Huntingdon, UK) were employed. Upon arrival, all mice were allowed to rest for 1 week previous to the first immunization. Moreover, they were randomly distributed into six separate cages according to the number of groups required in the experiment (groups A to F). Animals were provided food and water ad libitum.

Six groups (group A to F) of $n=5$ (in exception of group $\mathrm{A}, n=3$ and group $\mathrm{B}, n=4$ ) were immunized twice subcutaneously (s.c) at the base of the tail with a 21-day intervals. In group A, mice were not immunized (control group). In the rest of the groups (groups B to F), a dose of $15 \mu \mathrm{g} /$ animal of conserved HA-epitope NG-34 was injected alone (group B) or adjuvanted with $\mathrm{AH}$ (group C), AddaVax (group D), CAF01 (group E) or Diluvac Forte (group F) (Table 2). Three weeks after the second immunization, all animals were euthanized.

Sampling from each individual of the study was performed 3 weeks after the second immunization, at day 42 (termination day) when blood, spleens and inguinal lymph nodes were collected.

\section{Adjuvants and vaccine preparation}

CAF01, Diluvac Forte ${ }^{\circledR}$ (Statens Serum Institut, Copenhagen, Denmark), AddaVax ${ }^{\mathrm{TM}}$ (Invivogen, Toulouse, France) and aluminium hydroxide $(\mathrm{Al}(\mathrm{OH}) 3$, Alhydrogel 2.0\%) (Croda Biosector, Frederikssund, Denmark) were the adjuvants employed.

Mouse vaccines with an end volume of $200 \mu \mathrm{L}$ were prepared by mixing the antigen $(15 \mu \mathrm{g} /$ animal/dose $)$ dissolved in Tris-buffer with $9 \%(\mathrm{w} / \mathrm{v})$ trehalose, in a ratio of 1:1 with the adjuvant except for Alhydrogel $2.0 \%$ (each vaccine comprised $500 \mu \mathrm{g}$ aluminum content $/ 200 \mu \mathrm{L}$ ) $[19,20]$ and group A which was not immunized.

Table 2 Representation of the six mice groups (Groups A-F)

\begin{tabular}{lllll}
\hline Group & $\boldsymbol{n}$ & Antigen & Adjuvant & $\begin{array}{l}\text { Inoculation } \\
\text { route }\end{array}$ \\
\hline A & 3 & - & - & - \\
B & 4 & NG-34 & - & S.C. \\
C & 5 & NG-34 & Alhydrogel 2.0\% & S.C. \\
D & 5 & NG-34 & AddaVax & S.C. \\
E & 5 & NG-34 & CAF01 & S.C. \\
F & 5 & NG-34 & Diluvac Forte ${ }^{\circledR}$ & S.C. \\
\hline
\end{tabular}

$n=$ number of mice; $s . c=$ subcutaneously.
CAF01 was freshly prepared in agreement with other studies and comprised: $250 \mu \mathrm{g} / 50 \mu \mathrm{g}$ dimethyldioctadecylammonium (DDA)/trehalose 6,6 V-dibehenate (TDB) $/ 100 \mu \mathrm{L}[8,19]$.

\section{Cells, antigens and viruses}

Madin-Darby Canine Kidney (MDCK, ATCC CCL34) cells were used in the seroneutralization assays. They were properly cultured in Dulbecco's Modified Eagle Medium (DMEM) supplemented with 10\% fetal bovine serum (FBS), 1\% penicillin/streptomycin and $1 \%$ L-glutamine.

NG-34 epitope predicted by ISM was synthesized by GL Biochem Ltd, Shanghai, China. Its sequence corresponds with 34 amino acids in the HA1 region from the strain A/Catalonia/63/2009 (pH1N1) [GenBank ACS36215] [11].

Purified HA from A/California/04/09(H1N1)pdm09 and from A/Aichi/2/1968(H3N2) were purchased from Sino Biological, Beijing, China (cat. no. 40340-V08B and 11707-V08H, respectively).

SwH1N1 (A/swine/Spain/003/2010 H1N1 IV) [GenBank JQ319725 and JQ319727] and SwH3N2 (A/swine/ Spain/003/2010 H3N2 IV) [GenBank JQ319724 and JQ319726] were the viruses used.

\section{Organ preparation}

Spleens and lymph nodes were treated as follows: they were forced through a $70 \mu \mathrm{M}$ filter nylon mesh (BD Biosciences, San Jose, CA, USA), suspended in Roswell Park Memorial Institute (RPMI) media without FBS and further centrifuged for $5 \mathrm{~min}$ at $1800 \mathrm{rpm}$. At that point, cells were resuspended in $1 \mathrm{~mL}$ using complete RPMI (cRPMI) (supplemented with HEPES, penicillin-streptomycin, sodium pyruvate, L-glutamine and non-essential amino acids) with $10 \%$ FBS (v/v). Finally, all samples were counted using NucleoCassetes (ChemoMetec A/S, AllerØd, Denmark) on the NucleoCounter ${ }^{\circledR} \mathrm{NC}-100^{\mathrm{TM}}$ (reagents and materials from ChemoMetec A/S, AllerØd, Denmark).

\section{Immunoassays in mice for antigen-specific serum antibodies}

Maxisorb Plates (Nunc) were coated with $2 \mu \mathrm{g} /$ well of either NG-34 epitope or HA: A/California/04/09 (H1) in buffer carbonate bicarbonate $\mathrm{pH}=9.6$ and left to incubate overnight at $4{ }^{\circ} \mathrm{C}$. The next day, the plates were blocked during $1 \mathrm{~h} 30 \mathrm{~min}$ at room temperature (RT) using 2\% BSA PBS solution. Mouse sera were analyzed in threefold dilution series in PBS with $1 \%$ BSA, starting with a 30-fold dilution. After a 2-hour incubating period at RT and three washes with $0.2 \%$ Tween 20 PBS buffer, HRP-conjugated secondary antibodies (rabbit 
anti-mouse IgG1; Southern Biotech, Birmingham, AL, USA; and IgG2c; Invitrogen, San Diego, CA, USA) were added with 1\%BSA PBS at dilutions: 1:20 000 (IgG1) or 1:5000 (IgG2c) and incubated during $1 \mathrm{~h}$ at RT. Reiteratively, the plates were washed and developed using $3,3^{\prime}$, 5, 5'-tetramethylbenzidine (TMB) substrate (Kem-EnTec Diagnostics, Kuldyssen, Denmark). The reaction was later stopped by adding $0.2 \mathrm{M} \mathrm{H}_{2} \mathrm{SO}_{4}$ and the plates were read using a two-step fully automated ELISA (Hamiltion Starlet System, Switzerland) at 450-620 nm wavelength.

\section{Intra-cellular flow cytometry staining for mice splenocytes stimulated in vitro with NG-34 antigen}

In splenocytes, the production of cytokines IFN- $\gamma$, TNF$\alpha$, IL- 2 and IL-17 was assessed in the T cell population. For that purpose, cells were stained similarly as described in [21] but with few modifications. Briefly, splenocytes $\left(10^{6}\right.$ cells/well) were stimulated with $2 \mu \mathrm{g} / \mathrm{mL}$ of NG-34 peptide during $1 \mathrm{~h}$ at $37{ }^{\circ} \mathrm{C}$ and subsequently, incubated $6 \mathrm{~h}$ at $37^{\circ} \mathrm{C}$ with brefeldin $\mathrm{A}(2.5 \mu \mathrm{g} / \mathrm{mL})$ in order to block cytokine production. After this period, cells remained $\mathrm{O} / \mathrm{N}$ at $4{ }^{\circ} \mathrm{C}$. Additionally, from each group two pools were differentially made: not stimulated (negative control) or stimulated with PMA/ionomycin (positive control). Next day, all cells were stained utilizing the antibodies: CD4-BV786 (BD Pharmingen, San Diego, CA, USA; 56331), CD44-FITC (eBioscience, Frankfurt, Germany; 11-0441), CD8-PerCpCy5.5 (eBioscience, 45-0081). The cells were then permeabilized using fix/ perm (BD) and washed in permeabilization wash (BD). Subsequently, the cells were stained with IL-2-APCCy7 (BD Pharmingen, 560547), TNF- $\alpha$-PE (eBioscience, 12-7321), IFN- $\gamma$-PE-Cy7 (eBioscience, 25-7311) and IL17a-APC (eBioscience, 17-7177). The cells were acquired on a FACS Fortessa instrument using DIVA software (BD Bioscience, USA) and all the data analyzed using FlowJo software (Tree Star Inc.). Upon their acquisition, the cells were gated following this pattern: live $>$ singlets $>$ lymphocytes $>\mathrm{CD} 3+>\mathrm{CD} 4+$ versus $\mathrm{CD} 8+$. Furthermore, cytokine-producing cells (IFN- $\gamma$, IL-2, IL-17 and TNF- $\alpha$ ) within the CD4+CD44 high population were measured. Compensation beads (BD Pharmingen, USA) were used to compensate the fluorophores.

\section{Flow cytometry staining in mice for cells in the inguinal lymph nodes}

Cells from the inguinal lymph nodes were collected from all individuals; the cells were plated $\left(10^{6}\right.$ cells/well $)$ and treated with Mouse BD Fc Block ${ }^{\mathrm{TM}}$ (BD Pharmingen, 553142) to block non-antigen-specific bindings of immunogloblulins to Fcy III and Fcy II receptors. Two panels of antibodies were used to stain cell populations in the germinal centers (GC) of the lymph nodes; GC B cells
$\left(\mathrm{B} 220^{+} \mathrm{IgD}^{-} \mathrm{CD}^{-} 8^{-} \mathrm{GL7}^{+}\right)$and $\mathrm{T}$ follicular helper cells

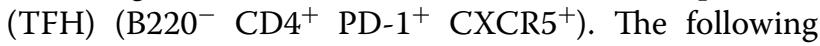
antibodies were mixed in PBS 1\% FBS: GL7-FITC (BioLegend GmbH, Koblenz, Germany; 144604), IgG1-PE (BD Pharmingen, 550083), B220-PerCP-Cy5.5 (BD Pharmingen, 552771), CD38-PE-CY7 (eBioscience, 25-0381) and IgD-BV786 (BD Pharmingen, 563618) to stain the B cells in the GC. To stain the TFH cell population, the following antibody panel was used: CD4-FITC (BD Pharmingen, 553047); CD279(PD1)-PE (BD Pharmingen, 551892); CD45R(B220)-PerCP-Cy5.5 (eBioscience, 65-0865-14), CXCR5-BV421 (BD Pharmingen, 562889) and live/deadEF780 (BD Pharmingen, 562889). After an incubation period of $30 \mathrm{~min}$ at $4{ }^{\circ} \mathrm{C}$, the cells were acquired on the FACS LSRII instrument using DIVA software (BD Bioscience, USA) and all the acquired data analyzed using FlowJo software (Tree Star Inc.). Compensation beads (BD Pharmingen, USA) were used to compensate the fluorophores.

\section{Mouse cytokine assay}

Splenocytes were seeded $\left(2 \times 10^{5} /\right.$ well $)$ and stimulated with the NG-34 epitope $(5 \mu \mathrm{g} / \mathrm{mL})$; media cRPMI (as negative control) and concavalin A $(1 \mu \mathrm{g} / \mathrm{mL})$ (as positive control) (GE Healthcare, Marlborough, MA, USA). The supernatants were harvested after $72 \mathrm{~h}$ incubation at $37^{\circ} \mathrm{C}$ and a 9-plex panel MSD standard Th1/Th2/Th17 which checks IFN- $\gamma$, TNF- $\alpha$, IL- 5, IL-10, IL-13 and IL-17 cytokines together with two U-plex panels for IL-6 and IL-1 $\beta$ detection were ran following the manufacturer's instructions (MSD, Rockville, MD, USA).

\section{Hemagglutination inhibition (HI) assay and serum neutralization test (SNT)}

Specific hemagglutination inhibition (HI) titers in mice sera were determined as the reciprocal of the later dilution of sera that inhibited hemagglutination. The protocol was adjusted to the recommendations provided by the World Organization for Animal Health (OIE) [22]. Samples from each group were pooled and ran in duplicates. A positive and negative reference serum (GD Animal Health, Deventer, The Netherlands) were also included in the assays to validate the technique.

Specific seroneutralizing antibody titers were evaluated. First, samples from each mice group were pooled, heat inactivated $\left(56{ }^{\circ} \mathrm{C}\right.$ for $\left.30 \mathrm{~min}\right)$, diluted two-fold with DMEM (supplemented with $1 \%$ penicillin/streptomycin and $1 \%$ L-glutamine) and incubated for $2 \mathrm{~h}$ at $37{ }^{\circ} \mathrm{C}$ with $100 \mathrm{TCID}_{50} /$ well with the SwH1N1 (A/ swine/Spain/003/2010 H1N1 IV) and SwH3N2 (A/ swine/Spain/003/2010 H3N2 IV) previously treated with porcine-trypsin (Sigma-Aldrich, St. Louis, MO, USA). Later on, the mixture of sera-virus was transferred into 
pre-washed plates with confluent MDCK cells and kept at $37{ }^{\circ} \mathrm{C}$ with $5 \% \mathrm{CO}_{2}$. After 7 days, the cytopathic effect (CPE) was read and the titers were expressed as the reciprocal dilution of serum that neutralized $100 \mathrm{TCID}_{50}$ of the challenged strain in $50 \%$ of the cultured replicates. Furthermore, in each plate there were added media controls (no virus), virus controls (no serum) and positive and negative reference sera from GD Animal Health, The Netherlands.

\section{Statistical analysis}

For statistical analysis, Prism 6 software (GraphPad v6.01, San Diego, CA, USA) was used. One-way ANOVA or a non-parametric test (Friedman test) followed by Dunnett multiple comparisons test was performed (assigning as control group: group B, the non-adjuvanted group). Statistically significant differences detected are illustrated by asterisks in each figure and explained in the corresponding figure legends.

\section{Results}

Specific humoral immune responses after 2 nd vaccination IgG1 and IgG2c antibody responses were analyzed against the NG-34 epitope and against the complete HA from A/California/04/09 (H1N1) (Figure 1). NG34specific IgG1 titers were higher in AH+NG-34 and CAF01 + NG-34 groups, displaying statistically significant differences $(P<0.05)$ when compared with the nonadjuvanted group (Figure 1A). Regarding NG34-specific IgG2 titers, the CAF01 + NG-34 mice group achieved the highest titers with statistically major significant differences $(P<0.0001)$ when compared to the non-adjuvanted group (Figure 1B). The rest of the adjuvanted groups $($ AH + NG-34, Addavax + NG-34, Diluvac Forte + NG34) were barely inducing IgG2c titers. Furthermore, HA1specfic IgG1 and IgG2c titers were also in concordance with the NG-34 specific antibody titers (Figures $1 \mathrm{C}$ and D). The AH + NG-34 group elicited high HA1-specific antibody levels $(P<0.05)$ but only the CAF01+NG34 group achieved significant statistical differences for both

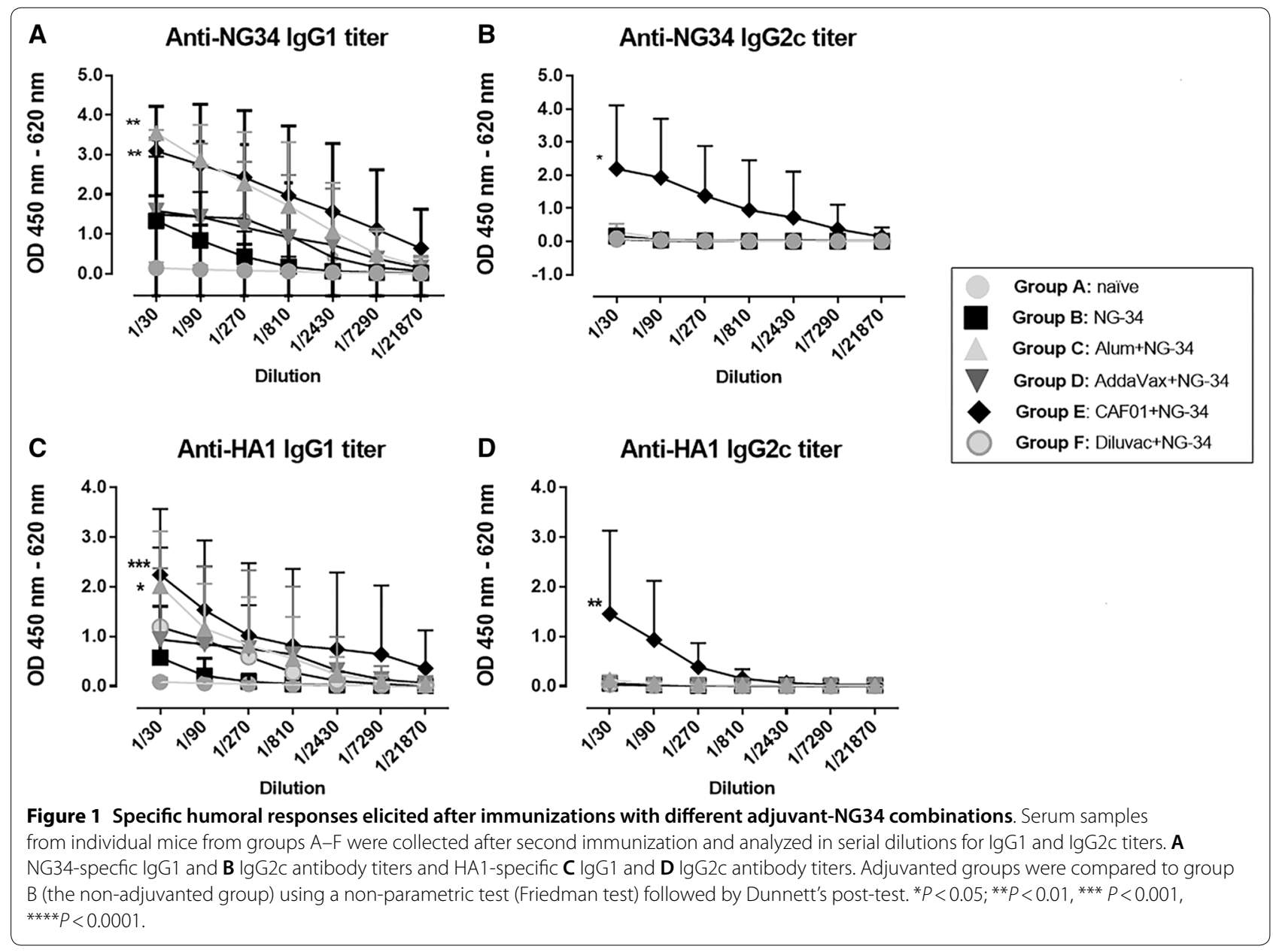


of the IgG1 $(P<0.001)$ and IgG2 $(P<0.01)$ antibody titers against the non-adjuvanted group $(P<0.01)$.

\section{Specific cellular immune responses in the spleen}

NG-34 antigen-specific cellular response was measured in the spleen. Intracellular CD4 and/or CD8 specific cytokines produced upon NG-34 stimulation was analyzed by flow cytometry. While in all the groups CD4 $\mathrm{T}$ cell response was observed, the CD8 $\mathrm{T}$ cell response was merely present. In parallel, percentages of $\mathrm{CD} 4+\mathrm{CD} 44$ high $\mathrm{T}$ cells in NG34-stimulated spleens were also determined. The $\mathrm{AH}+\mathrm{NG}-34$ and CAF01 + NG-34 groups showed the highest percentages $(P<0.05)$ in comparison to group B (Figure $2 \mathrm{~A})$. Only the CAF01 + NG-34 mice group demonstrated significant differences in intracellular cytokine, IFN- $\gamma(P<0.001)$, IL-2 $(P<0.05)$ and TNF- $\alpha(P<0.01)$ produced by NG-34 stimulated spleens (Figures $2 \mathrm{~B}-\mathrm{D}$ ). Additionally, IL-17 producing cells were the highest in the CAF01 + NG-34 group although no statistical differences were observed among different adjuvant/NG-34 combinations (Figure 2E).
Supernatants of NG34-stimulated spleens harvested after $72 \mathrm{~h}$ were analyzed with a multiplex system for different cytokines like IFN- $\gamma$, TNF- $\alpha$, IL-5, IL-10, IL-13 and IL-17 (Th1/Th2/Th17 type). Similarly, IL-6 and IL-1 $\beta$ levels were also evaluated (Figure 3). Statistically significant differences in IFN- $\gamma(P<0.001)$, TNF- $\alpha(P<0.01)$, IL-10 $(P<0.001)$, IL-17 $(P<0.001)$, IL-6 $(P<0.01)$ and IL-1 $\beta(P<0.001)$ cytokine release were only detected in the CAF01+NG-34 group when compared to the non-adjuvanted group (Figures 3A, B, D, F-H). IL-5 in the $\mathrm{AH}+\mathrm{NG}-34$ group (Figure $3 \mathrm{C}$ ) and IL-13 in the CAF01 + NG-34 group (Figure 3E) were detected at low concentrations although no statistically significant differences were observed in IL-5 and IL-13 among the groups.

\section{Alteration in the inguinal lymph node cell population in immunized mice}

Differences in the number of cells present in the GC of lymph nodes were detected. Significantly higher percentages of $\mathrm{B}$ cells $(P<0.005)$ were observed in the CAF01+NG-34 group (Figure 4A). In contrast, no statistical differences were observed in TFH cells, although

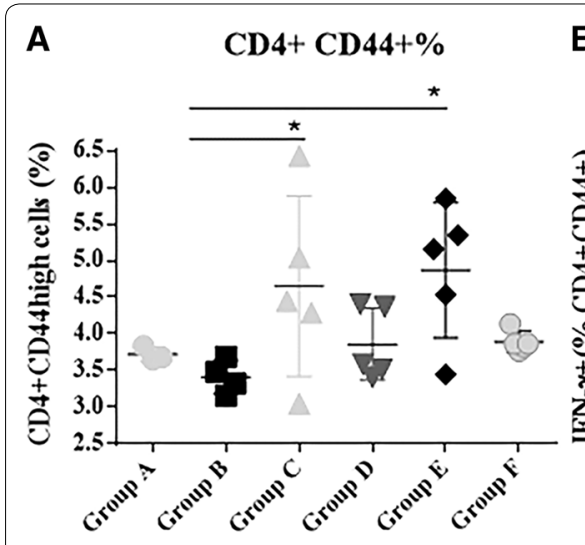

B IFN- $\gamma+\% \quad$ C

C $\quad$ IL-2+\%

D
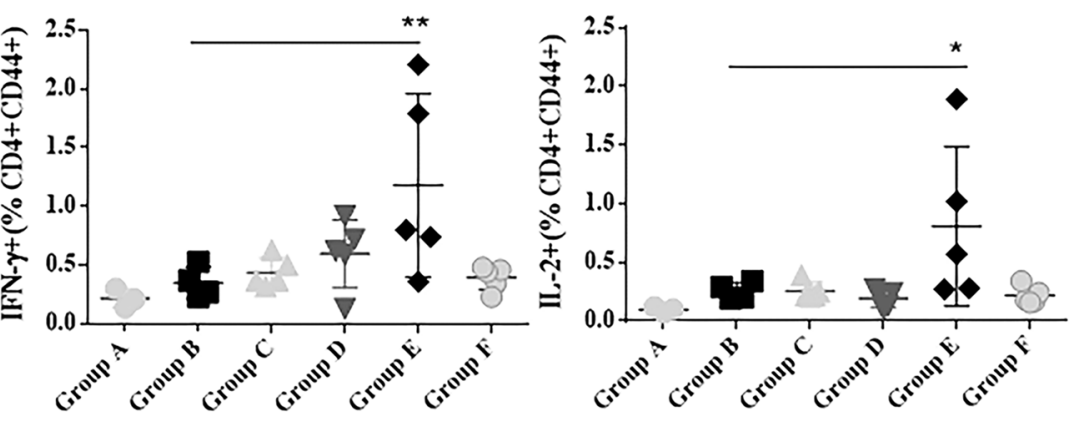

TNF- $\alpha+\%$

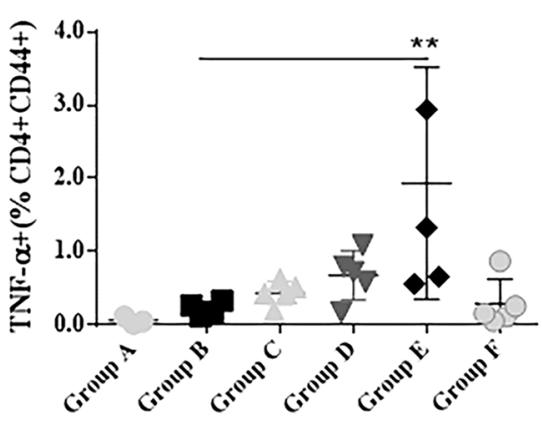

E

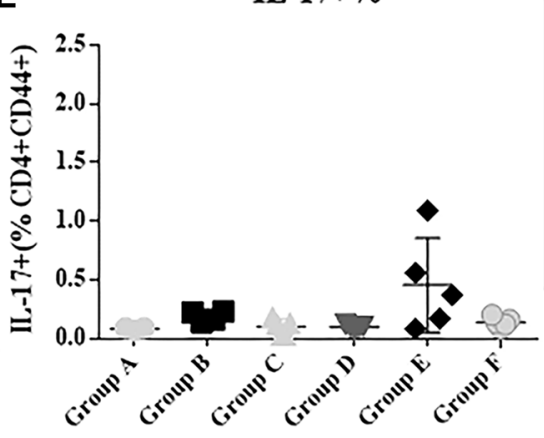

Group A: naïve

Group B: NG-34

Group C: Alum+NG-34

$\nabla$ Group D: AddaVax+NG-34

- Group E: CAF01+NG-34

Group F: Diluvac+NG-34

Figure 2 Cellular responses in the spleens of immunized mice. NG34-stimulated spleen cells from individual mice (groups A-F) were collected and analyzed for cytokine production by flow cytometry. Percentages of $\mathbf{A}$ CD4 + CD44high, B CD4+CD44high IFN- $\gamma$, C CD4 + CD44high IL-2, D CD4 + CD44high TNF-a and E CD4 + CD44high IL-17 (2) are represented. 


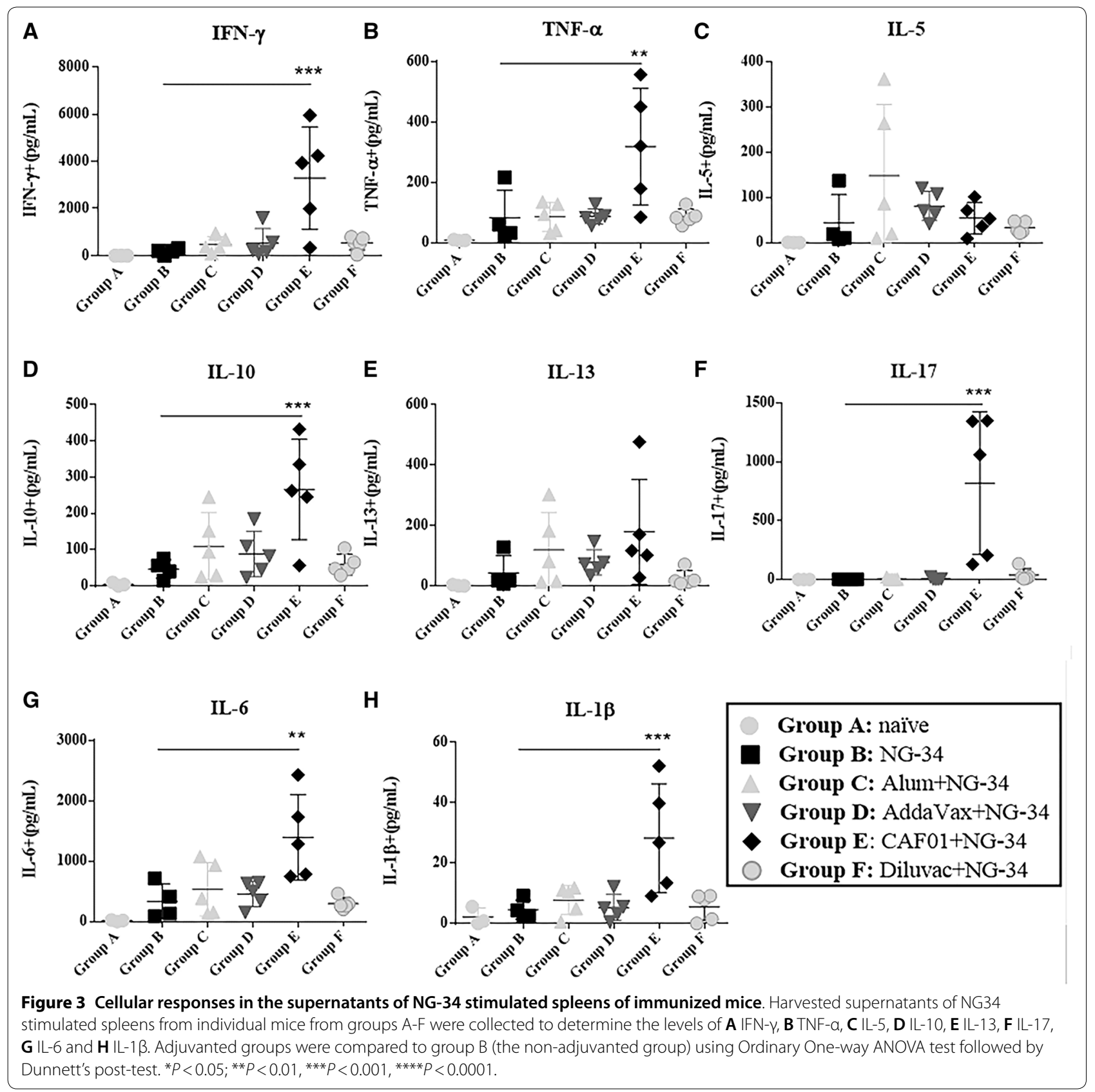

in CAF01 + NG34 and Diluvac Forte + NG-34 groups an increase in TFH was noticed (Figure 4B).

\section{Obtained $\mathrm{HI}$ and SNT titers in mouse sera}

HI titers were negative in all mice sera for each of the tested IV. SNT titers were either negative or low $(1: 10)$ in CAF01 + NG-34 and Diluvac Forte + NG-34 groups against SwH1N1 virus. Against SwH3N2 virus, both groups (CAF01+NG-34 and Diluvac Forte+NG-34) achieved a 1:40 titer (Table 3).

\section{Discussion}

Many immunogens/subunit antigens do not show strong immunogenicity, making the use of adjuvants necessary to reinforce their immune effect. In the present study, we focused on selecting the most suitable adjuvant that could better aid immunogenically when administered in combination with the NG-34 conserved HA-epitope.

Various groups of mice were either not immunized or immunized with NG-34 epitope alone or combined with adjuvants: AH, AddaVax, CAF01 and Diluvac Forte ${ }^{\circledR}$. 

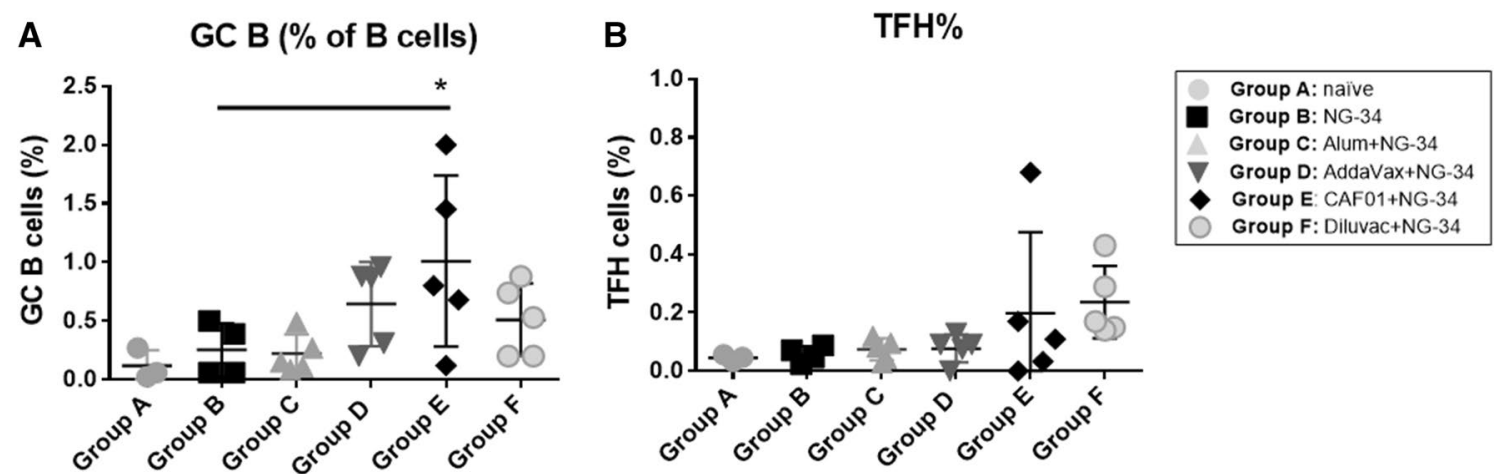

Figure 4 Changes in inguinal lymph node population. Lymph nodes samples from individual mice (groups A-F) were collected and analyzed by flow cytometry $\mathbf{A}$ the percentage of $\mathbf{B}$ cells in the GC (B) the percentage of TFH. Adjuvanted groups were compared to the non-adjuvanted group using Ordinary One-way ANOVA test followed by Dunnett's post-test. ${ }^{*} P<0.05 ;{ }^{* *} P<0.01,{ }^{* *} P<0.001$, ${ }^{* * *} P<0.0001$.

Table 3 SNT titers obtained from the six mice groups (groups A-F) against SwH1 N1 and SwH3N2 isolates

\begin{tabular}{llll}
\hline Group & Adjuvant & \multicolumn{2}{l}{ SNT titers } \\
\cline { 3 - 4 } & & Against SwH1N1 & $\begin{array}{l}\text { Against } \\
\text { SwH3N2 }\end{array}$ \\
\hline A & - & - & - \\
B & - & - & - \\
C & Alhydrogel 2.0\% & - & - \\
D & AddaVax $^{\text {TM }}$ & - & - \\
E & CAF01 & $1: 10$ & $1: 10$ \\
F & Diluvac Forte $^{\circledR}$ & $1: 40$ & $1: 40$ \\
\hline
\end{tabular}

SNT = serum neutralization test.

Interestingly, mice vaccinated with CAF01 + NG-34 elicited specific humoral and cellular immune responses to the conserved NG-34 HA-epitope (Figures 1 and 2), a dual immune induction widely considered ideal for an IV vaccine.

The AH + NG-34 group induced a polarized Th2-type response leading to significantly higher NG34-specific IgG1 titers (Figures 1A and 2A), and CAF01 combined with NG-34, promoted the highest levels of IgG1 (Figure 1A). The CAF01-NG-34 group also induced an IgG2c response, being the only peptide/adjuvant combination capable of inducing such a response (Figure 1B) which is in line with other studies published using other antigens and CAF01 $[8,20]$. These induced IgG2a/c titers are regarded as an important component for IV vaccines since they mediate protection when virus neutralizing titers are absent $[23,24]$.

Strong HI titers were not induced by any of the evaluated epitope/adjuvant combinations. Only CAF01 + NG-34 and Diluvac Forte + NG-34 groups displayed SNT titers albeit at low levels (Table 3). These results did not correlate with the high $\mathrm{HI}$ titers induced when using MF59 adjuvant in IV vaccines $[25,26]$. Perhaps, MF59-like adjuvants (Addavax) function better when the complete HA or IV strain are included in the vaccine formulation [27, 28]. Furthermore, the Addavax + NG-34 group did not boost Th1 and Th2 as demonstrated in other studies $[25,26]$. In contrast, our results were concordant with results using CAF01 combined with TIV, which conferred protection in an IHAindependent manner [29].

To achieve cross-protection between heterologous strains, an appropriate $\mathrm{T}$-cell response seems to be necessary [30]. In this work, the highest cellular responses were exhibited by the AH+NG-34 and CAF01+NG-34 groups (Figure 2A). The results obtained in the AH+NG-34 partly correlated with the trend for a predominant Th2 differentiation and Th2-type cytokine profile, usually promoted by aluminum salts $[31,32]$. Statistically significant increase in CD4 CD44high population and highest IFN- $\gamma$, IL-2 and TNF- $\alpha$ responses (Th1-type cytokines) were observed in mice from CAF01 + NG34 (Figures 2A and $C)$ as also reported in other studies $[6,19,33$, 34]. Significantly higher titers of IFN- $\gamma$, TNF- $\alpha$, IL-10, IL-17, IL- 6 and IL-1 $\beta$ were also observed in the NG34stimulated spleen cell supernatants obtained from the CAF01 + NG-34 vaccinated animals (Figures 3A, B, D, $\mathrm{F}-\mathrm{H})$. These results could be associated with the role of CAF01 in inducing Th1-cytokines and also with the property of one of the CAF01 compounds (the TDB) which leads to the secretion of IL-1 $\beta$, IL- 6 and TNF- $\alpha$ [35]. Furthermore, the rise in IL-17 levels of the mice from CAF01 + NG-34 (Figure 3F) could be related to the Th17 response that CAF01 promotes through the TLR-independent Syk/Card9-dependent pathway [36] (Figure 2). Other cytokines not from a Th1/Th17 profile were also boosted (IL-10 and IL-6) by CAF01 + NG-34 
vaccinated mice (Figures $3 \mathrm{D}$ and G). IL-10 induction could be related to the CD4 TFH cells which might promote $B$ cell proliferation, survival, and differentiation into antibody-secreting plasma cells [37-42].

The mice immunized with CAF01 + NG-34 displayed the greatest percentages of $B$ cells population in the $G C$ in the draining lymph nodes (Figure 4A). Other studies have reported CAF01 as an enhancer of GC reaction in comparison to other adjuvants such as AddaVax, aluminum hydroxide and CpG ODN 1826 [43] and recognized that this reaction is primordial for generating plasma and memory B cells [44]. In terms of the percentage of $\mathrm{TFH}$, the highest percentage mean was achieved by the Diluvac Forte + NG-34 but followed immediately by the CAF01 + NG-34 group (Figure 4B). Although not statistically significant, these data are of great relevance since the TFH cells promote long-lasting humoral immunity arising from the GC. CAF01 has been reported to have a more than a year duration inducing CMI responses due to its DDA compound which forms a depot at the injection site [45].

The TDB component of CAF01 is essential for the induction of $\mathrm{CMI}$ responses and that it is recognized via the C-type lectin receptor MINCLE (CLEC4E). It is important to note that there may be species-specific differences in recognition and activation of this MINCLE receptor. It is well known that CAF01 is a promising adjuvant in humans, inducing both antibody and CMI responses $[16,34]$ and also that CAF01 combined with Chlamydia trachomatis fusion proteins (Hirep1 and CTH93) induce strong CMI responses in Göttingen minipigs [46]. Nevertheless, whether TDB is also an effective immunostimulator in poultry remains to be assessed and further studies are therefore required to develop the CAF01 + NG-34 as a vaccine for poultry.

As a first step, this study may provide insights into what may be occurring when administering CAF01+NG-34 to influenza hosts (such as pig and poultry). With regards to the released umbrella of cytokines as well as antibodies induced, CAF01 ought to be a potential adjuvant to be mixed with the conserved NG-34 epitope.

\footnotetext{
Abbreviations

AH: aluminium hydroxide; ADCC: antibody-dependent cellular cytotoxicity; ARRIVE: Animal Research Reporting of In Vivo Experiments; BSA: bovine serum albumin; CAF01: cationic adjuvant formulation; CD4/CD8: cluster of differentiation; CMI: cell-mediate immune; CPE: cytopathic effect; DDA: dimethyldioctadecylammonium (DDA); DMEM: Dulbecco's Modified Eagle Medium; ELISA: enzyme-linked imunosorbent assay; FBS: fetal bovine serum; GC: germinal centers; HA: hemagglutinin; HI: hemagglutination inhibition; IFN: interferon; Ig: immunoglobulin; IL: interleukin; IVs: influenza viruses; ISM: Informational spectrum methodology; MDCK: Madin-Darby Canine Kidney; OlE: World Organization for Animal Health; PBS: phosphate-buffered saline; RBS: receptor binding site; RPMI: Roswell Park Memorial Institute; QIV: quadrivalent inactivated vaccine; RT: room temperature; SC: subcutaneous; SNT: serum neutralization test; SSI: Statens Serum Institut; TCID $_{50}$ : median tissue culture infectious dose;
}

TDB: trehalose 6,6 V-dibehenate; TFH: T follicular helper cells; Th:T helper; TMB: 3, 3',5,5'-tetramethylbenzidine; TIV: trivalent inactivated vaccine.

\section{Acknowledgements}

Authors thank the animal caretakers' from SSI animal facilities and Janne Rabech and Rune Fledelius Jensen for their dedication and technical assistance provided during the experiments. Authors also show gratitude to CESAC (Centre de Sanitat Avícola de Catalunya, Reus, Spain) personnel for supplying the chicken red blood cells (cRBCs) for the HI assays.

\section{Authors' contributions}

MSO, GKP, DC and AD planned and designed the study, interpreting the final results. $D C$ and $A D$ obtained its funding; MSO wrote the manuscript with detailed inputs and revisions from GKP, DC and AD. MSO and GKP prepared the vaccines, sampled the organs, developed the immunoassays, acquired the data from the flow cytometry and performed the mouse cytokine assays. MSO, SLS and LC performed and analyzed the HI and SNT data. MSO and GKP performed the statistical analysis. All authors read and approved the final manuscript.

\section{Funding}

The present work was developed under the AGL2013-48923-C2-2-R project funds supported by Ministerio de Economía y Competitividad (MINECO)/ Spanish Government and the grants supported to M.S.O (scholarship $n^{\circ}$ : BES-2014-068506 and EEBB-I-17-12462). Also, financial support was received from TRANSVAC (730964). Funding from CERCA Programme/Generalitat de Catalunya to IRTA is also acknowledged. The funders had no role in study design, data collection and analysis, decision to publish, or preparation of the manuscript.

\section{Availability of data and materials}

The data supporting the conclusions of this article is attached within the article and its additional files.

\section{Ethics approval and consent to participate}

Mouse experiments took place at SSI animal facilities. Vaccination and samplings developed strictly complied with the Danish legislation based on EU Directive 63/2010 and the conditions set for the animal experiment permission F2440 issued by The Animal Experiments Inspectorate. Animal Research: Reporting of In Vivo Experiments (ARRIVE) guidelines were also considered.

\section{Competing interests}

The authors declare that they have no competing interests.

\section{Author details}

${ }_{1}^{1}$ IRTA, Centre de Recerca en Sanitat Animal (CReSA, IRTA-UAB), Campus de la Universitat Autònoma de Barcelona, 08193 Bellaterra, Barcelona, Spain. ${ }^{2}$ Virus Research and Development Laboratory, Department of Virus and Microbiological Special Diagnostics, Statens Serum Institut, Artillerivej 5, 2300 Copenhagen S, Denmark.

Received: 8 October 2019 Accepted: 17 February 2020

Published online: 20 April 2020

\section{References}

1. Di Pasquale A, Preiss S, Tavares Da Silva F, Garçon N (2015) Vaccine adjuvants: from 1920 to 2015 and beyond. Vaccines 3:320-343

2. O'Hagan DT, Valiante NM (2003) Recent advances in the discovery and delivery of vaccine adjuvants. Nat Rev Drug Discov 2:727-735

3. Rappuoli R, Mandl CW, Black S, De Gregorio E (2011) Vaccines for the twenty-first century society. Nat Rev Immunol 11:865-872

4. Jalilian B, Christiansen SH, Einarsson HB, Jalilian B, Pirozyan MR, Petersen E, Vorup-Jensen T (2013) Properties and prospects of adjuvants in influenza vaccination-messy precipitates or blessed opportunities? Mol Cell Ther $1: 2$

5. Mbow ML, De Gregorio E, Valiante NM, Rappuoli R (2010) New adjuvants for human vaccines. Curr Opin Immunol 22:411-416

6. van Dissel JT, Joosten SA, Hoff ST, Soonawala DP, Prins C, Hokey DA, O'Dee DM, Graves A, Thierry-Carstensen B, Andreasen LV, Ruhwald M, de 
Visser AW, Agger EM, Ottenhoff TH, Kromann I, Andersen P (2014) A novel liposomal adjuvant system, CAF01, promotes long-lived Mycobacterium tuberculosis-specific T-cell responses in human. Vaccine 32:7098-7107

7. van Dissel JT, Arend SM, Prins C, Bang P, Tingskov PN, Lingnau K, Nouta J, Klein MR, Rosenkrands I, Ottenhoff TH, Kromann I, Doherty TM, Andersen P (2010) Ag85B-ESAT-6 adjuvanted with IC $31{ }^{\circledR}$ promotes strong and long-lived Mycobacterium tuberculosis specific T cell responses in naïve human volunteers. Vaccine 28:3571-3581

8. Agger EM, Rosenkrands I, Hansen J, Brahimi K, Vandahl BS, Aagaard C, Werninghaus K, Kirschning C, Lang R, Christensen D, Theisen M, Follmann F, Andersen P (2008) Cationic liposomes formulated with synthetic mycobacterial cordfactor (CAF01): a versatile adjuvant for vaccines with different immunological requirements. PLoS One 3:e3116

9. Matthews J (2006) Egg-based production of influenza vaccine: 30 years of commercial experience. In: Bugliearello G (ed) The Bridge. National Academy of Engineering, Washington DC, pp 17-24

10. Jang YH, Seong BL (2013) Toward a universal influenza vaccine: from the perspective of protective efficacy. Clin Exp Vaccine Res 2:71-73

11. Sisteré-Oró M, Vergara-Alert J, Stratmann T, López-Serrano S, Pina-Pedrero S, Córdoba L, Pérez-Maillo M, Pleguezuelos P, Vidal E, Veljkovic V, Segalés J, Nielsen J, Fomsgaard A, Darji A (2019) Conserved HA-peptide NG34 formulated in PCMV-CTLA4-Ig reduces viral shedding in pigs after a heterosubtypic influenza virus SwH3N2 challenge. PLoS One 14:e0212431

12. Veljkovic V, Veljkovic N, Muller CP, Müller S, Glisic S, Perovic V, Köhler H (2009) Characterization of conserved properties of hemagglutinin of H5N1 and human influenza viruses: possible consequences for therapy and infection control. BMC Struct Biol 9:21

13. Veljkovic V, Niman HL, Glisic S, Veljkovic N, Perovic V, Muller CP (2009) Identification of hemagglutinin structural domain and polymorphisms which may modulate swine $\mathrm{H} 1 \mathrm{~N} 1$ interactions with human receptor. BMC Struct Biol 9:62

14. Vergara-Alert J, Argilaguet JM, Busquets N, Ballester M, Martín-Valls GE, Rivas R, López-Soria S, Solanes D, Majó N, Segalés J, Veljkovic V, Rodríguez F, Darji A (2012) Conserved synthetic peptides from the hemagglutinin of influenza viruses induce broad humoral and T-cell responses in a pig model. PLoS One 7:e40524

15. Sisteré-Oró M, Martínez-Pulgarín S, Solanes D, Veljkovic V, López-Serrano S, Córdoba L, Cordón I, Escribano JM, Darji A (2020) Conserved HApeptides expressed along with flagellin in Trichoplusia ni larvae protects chicken against intranasal H7N1 HPAIV challenge. Vaccine 38:416-422

16. Abraham S, Juel HB, Bang P, Cheeseman HM, Dohn RB, Cole T, Kristiansen MP, Korsholm KS, Lewis D, Olsen AW, McFarlane LR, Day S, Knudsen S, Moen K, Ruhwald M, Kromann I, Andersen P, Shattock RJ, Follmann F (2019) Safety and immunogenicity of the chlamydia vaccine candidate CTH522 adjuvanted with CAF01 liposomes or aluminium hydroxide: a first-in-human, randomised, double-blind, placebo-controlled, phase 1 trial. Lancet Infect Dis 19:1091-1100

17. Ferrari L, Borghetti P, Gozio S, De Angelis E, Ballotta L, Smeets J, Blanchaert A, Martelli P (2011) Evaluation of the immune response induced by intradermal vaccination by using a needle-less system in comparison with the intramuscular route in conventional pigs. Res Vet Sci 90:64-71

18. Visser N, Egger W, Lütticken D (1994) Intradermal application of Aujeszky's disease virus strain Begonia with tocopherol-based adjuvant and a novel design injection device. Acta Vet Hung 42:413-418

19. Knudsen NP, Olsen A, Buonsanti C, Follmann F, Zhang Y, Coler RN, Fox CB, Meinke A, D'Oro U, Casini D, Bonci A, Billeskov R, De Gregorio E, Rappuoli R, Harandi AM, Andersen P, Agger EM (2016) Different human vaccine adjuvants promote distinct antigen-independent immunological signatures tailored to different pathogens. Sci Rep 6:19570

20. Davidsen J, Rosenkrands I, Christensen D, Vangala A, Kirby D, Perrie Y, Agger EM, Andersen P (2005) Characterization of cationic liposomes based on dimethyldioctadecylammonium and synthetic cord factor from M. tuberculosis (trehalose 6,6'-dibehenate) — a novel adjuvant inducing both strong $\mathrm{CMI}$ and antibody responses. Biochim Biophys Acta 1718:22-31

21. Caproni E, Tritto E, Cortese M, Muzzi A, Mosca F, Monaci E, Baudner B, Seubert A, De Gregorio E (2012) MF59 and Pam3CSK4 boost adaptive responses to influenza subunit vaccine through an IFN type l-independent mechanism of action. J Immunol 188:3088-3098

22. World Organization for Animal Health (OIE). (2012) Manual of diagnostic tests and vaccines for terrestrial animals. Chapter 2.8.7. Influenza A virus of swine. http://www.oie.int/en/international-standard-setting/terrestria I-manual/access-online/. Accessed 12 Feb 2019

23. Wack A, Baudner BC, Hilbert AK, Manini I, Nuti S, Tavarini S, Scheffczik H, Ugozzoli M, Singh M, Kazzaz J, Montomoli E, Del Giudice G, Rappuoli R, O'Hagan DT (2008) Combination adjuvants for the induction of potent, long-lasting antibody and T-cell responses to influenza vaccine in mice. Vaccine 26:552-561

24. Jegaskanda S, Job ER, Kramski M, Laurie K, Isitman G, de Rose R, Winnall WR, Stratov I, Brooks AG, Reading PC, Kent SJ (2013) Cross-reactive influenza-specific antibody-dependent cellular cytotoxicity antibodies in the absence of neutralizing antibodies. J Immunol 190:1837-1848

25. Singh M, O'Hagan D (1999) Advances in vaccine adjuvants. Nat Biotechnol 17:1075-1081

26. Galli G, Medini D, Borgogni E, Zedda L, Bardelli M, Malzone C, Nuti S, Tavarini S, Sammicheli C, Hilbert AK, Brauer V, Banzhoff A, Rappuoli R, Del Giudice G, Castellino F (2009) Adjuvanted H5N1 vaccine induces early CD4 T cell response that predicts long-term persistence of protective antibody levels. Proc Natl Acad Sci USA 106:3877-3882

27. Oshansky CM, Zhou J, Gao Y, Schweinle JE, Biscardi K, DeBeauchamp J, Pavetto C, Wollish A, BRITE Study Coordination Team, Webby RJ, Cioce V, Donis RO, Bright RA (2019) Safety and immunogenicity of influenza $A(\mathrm{H} 5 \mathrm{~N} 1)$ vaccine stored up to twelve years in the National pre-pandemic influenza vaccine stockpile (NPIVS). Vaccine 37:435-443

28. Ko EJ, Kang SM (2018) Immunology and efficacy of MF59-adjuvanted vaccines. Hum Vaccin Immunother 14:3041-3045

29. Christensen D, Christensen JP, Korsholm KS, Isling LK, Erneholm K, Thomsen AR, Andersen P (2018) Seasonal influenza split vaccines confer partial cross-protection against heterologous influenza virus in ferrets when combined with the CAF01 adjuvant. Front Immunol 8:1928

30. Thomas PG, Keating R, Hulse-Post DJ, Doherty PC (2006) Cell-mediated protection in influenza infection. Emerg Infect Dis 12:48-54

31. HogenEsch H (2002) Mechanisms of stimulation of the immune response by aluminum adjuvants. Vaccine 20(Suppl 3):S34-S39

32. Brewer J (2006) (How) do aluminium adjuvants work? Immunol Lett 102:10-15

33. Osterhaus A, Fouchier R, Rimmelzwaan G (2011) Towards universal influenza vaccines? Philos Trans R Soc Lond B Biol Sci 366:2766-2773

34. Pedersen GK, Andersen P, Christensen D (2018) Immunocorrelates of CAF family adjuvants. Semin Immunol 39:4-13

35. Geisel RE, Sakamoto K, Russell DG, Rhoades ER (2005) In vivo activity of released cell wall lipids of Mycobacterium bovis bacillus Calmette-Guérin is due principally to trehalose mycolates. J Immunol 174:5007-5015

36. Werninghaus K, Babiak A, Gross O, Hölscher C, Dietrich H, Agger EM, Mages J, Mocsai A, Schoenen H, Finger K, Nimmerjahn F, Brown GD, Kirschning C, Heit A, Andersen P, Wagner H, Ruland J, Lang R (2009) Adjuvanticity of a synthetic cord factor analogue for subunit Mycobacterium tuberculosis vaccination requires FcRgamma-Syk-Card9-dependent innate immune activation. J Exp Med 206:89-97

37. Laidlaw BJ, Lu Y, Amezquita RA, Weinstein JS, Vander Heiden JA, Gupta NT, Kleinstein SH, Kaech SM, Craft J (2017) Interleukin-10 from CD4 + follicular regulatory $T$ cells promotes the germinal center response. Sci Immunol 2:eaan4767

38. Rousset F, Garcia E, Defrance T, Péronne C, Vezzio N, Hsu DH, Kastelein R, Moore KW, Banchereau J (1992) Interleukin 10 is a potent growth and differentiation factor for activated human B lymphocytes. Proc Natl Acad Sci USA 89:1890-1893

39. Choe J, Choi YS (1998) IL-10 interrupts memory B cell expansion in the germinal center by inducing differentiation into plasma cells. Eur J Immunol 28:508-515

40. Yoon SO, Zhang X, Berner P, Choi YS (2009) IL-21 and IL-10 have redundant roles but differential capacities at different stages of plasma cell generation from human germinal center B cells. J Leukoc Biol 86:1311-1318

41. Cai G, Nie X, Zhang W, Wu B, Lin J, Wang H, Jiang C, Shen Q (2012) A regulatory role for $\mathrm{IL}-10$ receptor signaling in development and $\mathrm{B}$ cell help of $\mathrm{T}$ follicular helper cells in mice. J Immunol 189:1294-1302

42. Guthmiller JJ, Graham AC, Zander RA, Pope RL, Butler NS (2017) Cutting edge: IL-10 is essential for the generation of germinal center $B$ cell responses and anti-Plasmodium humoral immunity. J Immunol $198: 617-622$ 
43. Ciabattini A, Pettini E, Fiorino F, Pastore G, Andersen P, Pozzi G, Medaglin D (2016) Modulation of primary immune response by different vaccine adjuvants. Front Immunol 7:427

44. McHeyzer-Williams M, Okitsu S, Wang N, McHeyzer-Williams L (2011) Molecular programming of B cell memory. Nat Rev Immunol 12:24-34

45. Henriksen-Lacey M, Bramwell VW, Christensen D, Agger EM, Andersen P, Perrie Y (2010) Liposomes based on dimethyldioctadecylammonium promote a depot effect and enhance immunogenicity of soluble antigen. J Control Release 142:180-186

46. Erneholm K, Lorenzen E, Bøje S, Olsen AW, Andersen P, Cassidy JP, Follmann F, Jensen HE, Agerholm JS (2016) Genital tract lesions in sexually mature Göttingen minipigs during the initial stages of experimental vaginal infection with Chlamydia trachomatis serovar D. BMC Vet Res 12:200

47. Gupta RK (1998) Aluminum compounds as vaccine adjuvants. Adv Drug Deliv Rev 32:155-172

48. Petrovsky N, Aguilar JC (2004) Vaccine adjuvants: current state and future trends. Immunol Cell Biol 82:488-496

49. Aimanianda V, Haensler J, Lacroix-Desmazes S, Kaveri SV, Bayry J (2009) Novel cellular and molecular mechanisms of induction of immune responses by aluminum adjuvants. Trends Pharmacol Sci 30:287-295

50. Marrack P, McKee AS, Munks MW (2009) Towards an understanding of the adjuvant action of aluminium. Nat Rev Immunol 9:287-293

51. Kuroda E, Coban C, Ishii KJ (2013) Particulate adjuvant and innate immunity: past achievements, present findings, and future prospects. Int Rev Immunol 32:209-220

52. Ott G, Barchfeld GL, Chernoff D, Radhakrishnan R, van Hoogevest P, Van Nest G (1995) MF59. Design and evaluation of a safe and potent adjuvant for human vaccines. Pharm Biotechnol 6:277-296

53. Podda A, Del Giudice G (2003) MF59-adjuvanted vaccines: increased immunogenicity with an optimal safety profile. Expert Rev Vaccines 2:197-203

54. Coffman RL, Sher A, Seder RA (2010) Vaccine adjuvants: putting innate immunity to work. Immunity 33:492-503
55. El Sahly H (2010) MF59 ${ }^{\mathrm{TM}}$ as a vaccine adjuvant: a review of safety and immunogenicity. Expert Rev Vaccines 9:1135-1141

56. O'Hagan DT, Ott GS, De Gregorio E, Seubert A (2012) The mechanism of action of MF59 - an innately attractive adjuvant formulation. Vaccine 30:4341-4348

57. Calabro S, Tritto E, Pezzotti A, Taccone M, Muzzi A, Bertholet S, De Gregorio E, O'Hagan DT, Baudner B, Seubert A (2013) The adjuvant effect of MF59 is due to the oil-in-water emulsion formulation, none of the individual components induce a comparable adjuvant effect. Vaccine 31:3363-3369

58. Christensen D, Marie Agger E, Andreasen LV, Kirby D, Andersen P, Perrie Y (2009) Liposome-based cationic adjuvant formulations (CAF): past, present, and future. J Liposome Res 19:2-11

59. Martel CJM, Agger EM, Poulsen JJ, Jensen TH, Andresen L, Christensen D, Nielsen LP, Blixenkrone-Møller M, Andersen P, Aasted B (2011) CAF01 potentiates immune responses and efficacy of an inactivated influenza vaccine in ferrets. PLoS One 6:e22891

60. Martelli P, Ferrari L, Morganti M, De Angelis E, Bonilauri P, Guazzetti S, Caleffi A, Borghetti P (2011) One dose of a porcine circovirus 2 subunit vaccine induces humoral and cell-mediated immunity and protects against porcine circovirus-associated disease under field conditions. Vet Microbiol 149:339-351

61. Karlsson I, Borggren M, Nielsen J, Christensen D, Williams J, Fomsgaard A (2017) Increased humoral immunity by DNA vaccination using an a-tocopherol-based adjuvant. Hum Vaccin Immunother 13:1823-1830

\section{Publisher's Note}

Springer Nature remains neutral with regard to jurisdictional claims in published maps and institutional affiliations.
Ready to submit your research? Choose BMC and benefit from:

- fast, convenient online submission

- thorough peer review by experienced researchers in your field

- rapid publication on acceptance

- support for research data, including large and complex data types

- gold Open Access which fosters wider collaboration and increased citations

- maximum visibility for your research: over $100 \mathrm{M}$ website views per year

At $\mathrm{BMC}$, research is always in progress.

Learn more biomedcentral.com/submissions 